\title{
The Strategic Planning of the Brazilian Federal Revenue: Comparative Analysis with Similar Organs from Other Countries
}

\author{
Antonio Carlos de Almeida \\ Receita Federal do Brasil, State University of Western Paraná - \\ Campus Cascavel, PR, Brazil
}

Claudio Antonio Rojo

Associate Professor of Master's Degree in Business Administration - PPGA

State University of Western Paraná - Campus Cascavel, PR - Brazil

Received: June 12, 2018 Accepted: July 5, 2018 Online published: July 16, 2018

doi:10.5296/jpag.v8i3.13260 URL: https://doi.org/10.5296/jpag.v8i3.13260

\begin{abstract}
The strategic planning is a fundamental instrument for the management organization. The public administration is increased in that area and it had taken measures with the necessary adjustment. This research has the purpose of comparing the strategic planning of the Brazilian Federal Revenue - RFB (in Portuguese: Receita Federal do Brasil) with congener institutions from other countries. Even thought, the information available is limited, this research is able to provide a wide vision about the realities of these sectors and about the strategies that they had taken. This is an exploratory study, with a qualitative method, that aims to compare cases. The results show that the Brazilian tax administration gets a strategic planning based in international standard and that the tax administration analyzed were similar, having, in general, the same strategic orientation directed to the obtained of resources, aimed to the State and its publics policies, to safeguard the tax base, to stimulate the voluntary deadline compliance, for innovates technological solutions and the search for being recognized and respected. It was also observed that in the tax administration from developed nations the vision of future is related to the confidence that society has in these organizations, result of a consolidated tax system and in the valorization of people.
\end{abstract}

Keywords: strategic, strategic planning, administration tax, Brazilian federal revenue 


\section{Introduction}

The strategy is not a recent subject and it was not created in the business environment, in fact its initial use was by the army and it was incorporated in the business world in 50's, because of the fact that the factories realized the necessity of being prepared for the future. Therefore, the academic circles show that the strategic assumes other meanings besides of a way of winning the enemy, as occurs in wars (Pereira, M. F., Agapito, F., Strada, R. J. S \& Almeida, M. I. R., 2007).

The function of the strategic is to orient an organization though the changes and transitions to assure its future growing and to sustain the success. It would be the relation between the organization and the external ambience (Abib \& Hoppen, 2015).

According to Pereira (1998), in the moment that some reforms were implanted in the public management of the country, there were necessities of orientate the bureaucratic public administration (self-referent, guide by their own necessities and perspectives) for the managerial public administration oriented for a citizen (focused on their own necessities and perspectives). This management approach in the Brazilian public administration was created in the 90ties and the federal governmental organizations adopted this orientation in their management.

The research problem is to analyze the strategic planning of the Brazilian Federal Revenue and comparing it with others tributary administrations. Therefore, the objective is to compare the administration tax from distinct countries. Offering comparative elements about the reality of these organs, this project provides knowledge about distinct realities, about particularly and shared scenes from each nation based in normal challenges that happening in these areas.

This assignment is divided in six parts. The first part is the introduction. In the second, the theoretical frame. The third part is the methodological procedure. The fourth part shows the results of the research, the fifth part is the comparative of the strategic planning and at last, the final considerations.

\section{Theorical References}

The strategic planning provides the organization and the self-affirmation to identify and offer a future and a way of achieving it. Therefore, the parts of the strategic planning: mission, vision, objectives and operation plans identify the profile of the organization (Fischmann \& Almeida, 1991). According to Ghemawat (2000), the word "strategy" is originated from a term created by the ancient Greeks, which has the meaning of magistrate or military Commander-in-Chief. For two millennia, it has the military meaning. However, the adaptation of the term into a business meaning had to wait because it was only adapted to that meaning in the Second Industrial Revolution, which began only in XIX, but it hit only in XX.

In addition, Ghemawat (2000) says that managers of the highest level of those firms felt the necessity of a strategic planning, so were they who articulated a strategic thought for the first time. For an example, Alfred Sloan, the company's main executive of the General Motors, from 1923 to 1946, created a well succeed strategy based in the strength and weakness of its biggest competing company, the Ford Motor Company, and put it in on paper after being 
retired. The Second World War provides an essential encouragement to the strategic thoughts of the business and the military fields because it grown the problem of the limited allocation of resources. Still according to the writer, it was in the 60 's that started the discussions at Administration colleges with focus in the combination of the strengths and weakness of the companies. This would be the distinctive competition, with its opportunities and threat faced in the market, which turn into the classic structure of analysis known as analysis SWOT, which become popular in the academics and managers fields because of the Harvard's political conference of business in 1973.

\subsection{The Strategic Planning in the Public Sector}

The data about the adjustments in the Brazilian State form are represented by Pereira (1998), who relates that, in the 90's it was focused in the State reform, in particular to the administrative reform. The administrative reform had the purpose of turn the public service more consistent to the contemporaneous capitalism, offering as one of its reason the fact that citizens were becoming more conscious, that the bureaucratic public administration did not respond to the demands that the civil society present to the governments. Therefore, instead of the old bureaucratic public administration, a new form of the administration based in progress which were experimented during the XX century, the business administration companies, without losing the features of the public administration: an administration that the concern is not the earnings, but the public demands.

Thereby, as the author said, the public administration grown in the second half of the XX century as an answer to the State crises; as a way of faces the fiscal crises; as a strategy to reduce the cost and to become the administration of the State's services more efficient; as an instrument of protecting the property.

Pereira (1998), also said that some basic characters that define the public administration managing is the fact of being oriented for the citizens and to the results; the presumption that the politicians and civil servant deserve a limited extant of confidence; as a strategy, it helps to decentralize and to incentive the creativity and innovation; the instrument that provides the control about the public manager is the manager contract. While the bureaucratic public administration is focus on the process; and in define the procedure of the staff recruitment; to buy products and service; and in satisfice the public demands, the managerial public administration is oriented to the results. While the bureaucratic public administration is self-referenced, the manager public administration is oriented for the citizen.

Stewart (2004) identifies three types of strategies in public sector, which are the political strategy, administration strategy and management strategy. The political strategy is what the government wants to change, its political agenda, and the ways that the agency is going to move to help it to achieve this agenda. The organizational strategy is similar to the private sector, this is what the organization does to understand the necessity and expectative of its interesting parts, what makes to support its future in a world where the competition pressure is not distant, even in the public sector. The manager strategy are the techniques activities of the preparation of budget and of reports, the vast array of the decision done, and the resource to get the agreed objectives, activities that are usually taken as unequivocally managerial in the way that they seem to be removed of the strategic field (Stewart, 2004). The focus, in this 
research, as was said, is the study of the administration strategy or organizational of the object organization of the search and similar from other countries.

\subsection{The Tributary Administration}

The public administration is structured by the legal order of the country. In the Brazilian case, the Constitution of the Republic, from 1998, stablished in chapter VII, from the Title III, which is related to the Estate organization, rules about the organization of the public administration. In the chapter I, from the Title VI, which is related to the tax and the budget, is based in the National Tax Code (Act $\mathrm{n}^{\mathrm{o}} 5.172$, of October $25^{\text {th }}$ from 1966), about the Title IV from the Brazilian administration tax from 1966 (CTN, 1966). The organization of the federal tax administration is based in the Act $n^{\circ} 11.457$ (Brazil, 2007). The public administration is, conform the CIAT - Inter-American Centre of Tax Administration, the activity designed by a State in order to provide, organize, direct, coordinate and control the public business, as required as interesting of the community. The guidelines emerge from the governmental politician about the approach of the common good, oriented to reach great national objectives. The purpose of this politician and of the legal rules that governing the public administration are usually necessary through the legislative power, which respond to the necessaries resources through the means act or budget (CIAT, 2015).

The tax administration is placed in the general public administration and it had similar characteristic and rules. Distinguish it, for being a manager of a public area responsible for applying rules contained in the tax system, as the control of the fiscal compliance of the contributors and the consequences of this appliance (CIAT, 2015).

The tax administration is focus in the organization, direction and control of the aspects related to the administration and appliance of rules about the tax that intend the satisfaction of the State necessities. Because of this, it is necessary stablishing the tributary relation in function of the taxable persons, collecting the tax and solving it, in the administrative area, the taxes controversy resulted of the taxpayer-tax relation. The biggest objective of the tax administration is to assure that with the necessary revenue for the financial of the State and its public politician be collected (CIAT, 2015).

\section{Methods and Techniques of Research}

This research applied a qualitative method, with an explanatory gender. Malhotra (2001) said that the explanatory research is used in cases where it is needed to find a problem with precision, identifying relevant actions or to obtain data for the development approach. Therefore, as the author, the objective of the explanatory research is to explore a problem or a situation to provide criterions and comprehension.

According to Beuren (2009), the characterization of the study as an explanatory research usually happens when there is low number of knowledge about a theme, search through the study getting to know the subject, turning it clearer or to construct relevant questions about the research.

When a case study involves two or more persons, two or more institutions, it can be said multiple cases, situation that the objective can be a description of more than one person, 
organization or event and it can also to have comparisons between them (Godoy, 1995a). Therefore, the research is characterized as a comparative study.

The organizations from other countries, to the comparative study, was define for convenience, in the north continent, including Argentina, Paraguay, Uruguay, Chile, United States of America and Canada.

The data of this study were collected from secondary sources, as official web pages of the organizations. According to Malhotra (2001), primary data are the ones that are generated by a researcher with the objective of solve problems at stake, whereas that the secondary ones were already collect for objectives that are not for the study problem.

The limitation of the research is caused by the unavailability of information that is related for the strategic organization. It is understood that the information about the general organization is treated in a reserved way, because of its peculiarity for the organization in a general way. However, the sources researched revel a wealth of information, minimizing the limitation said before.

\section{Research Results}

The tax administration is linked to the public administration from a specific country, which the responsibility is to apply a tax and to control the compliance of the tax regulation created by the legal rules of the state. This definition was created from studies developed in this research. It can be also said, that this definition, that is part of the objective of the tax administration, perform and assure the collect of the revenue that finances the State.

The Brazilian Federal Revenue Office (RFB) performs the federal tax administration in Brazil. The RFB is defined by its institutional normative rules, as a specific organ, singular, subordinated to the Ministry of Finance, responsible for the administration of the taxes of the Union, acting against and to prevent tributary crimes, such as fiscal frauds, smuggling, money laundering and other criminal acts related to the international market. Furthermore, it has the responsibility of finance the Federal Executive Power in the policy tax making (RFB, 2017). In the year of 2017 , the total value of the federal collected was about $R \$ 1.342 .408$ million (RFB, 2018). 
The institutional competence from the RFB is summarized in the Figure 1.

Institutional Competences from the RFB

Administration of the internal taxes and of external relations.

Managing and execution of the collecting actives, posting, administrative charge, inspection, search and fiscal inspection and control of the administrative account.

Managing and execution of administrative services, inspection and customs control.

Repression to the smuggling, in the limit of its competence.

Prepare and judgment, in first instance of the administrative process from determination and requirement of tributaries credits of the Union.

Interpretation, applying and elaboration of proposals to the improvement of the tax legislation and federal customs.

Subsidy to the formulation of the tributary policy and dutiable.

Subsidy to the formulation of revenues' budget and tributaries benefits of the Union.

Interaction with the citizen through distance or safe-to-face attendance service.

Fiscal Education to exercise the citizenship.

Formulation and policy management of fiscal economy information.

Formulação e gestão da política de informações econômico-fiscais.

Promoting of the integration with publics and private organs through accords to permute information, methods and techniques of fiscal action to the rationality of activities, moreover the delegation of competence.

Acting the international cooperation, implementation of agreements of international accords in terms of tributary and customs.

Figure 1. Institutional Competences from RFB

Source: Brazilian Federal Revenue Office (RFB, 2017).

\subsection{The Strategic Planning in the Brazilian Federal Revenue}

The strategic map of the RFB, from the period of 2016-2019, is showed in the Figure 2 . Through it is possible to have a visual perception about how the strategic planning is structured, based in 3 perspectives known as results objectives, process objectives and management and support objectives, that can be also understood as results perspectives, process perspectives and management and support perspectives. 


\section{Macrothink}

Journal of Public Administration and Governance

ISSN 2161-7104 2018, Vol. 8, No. 3

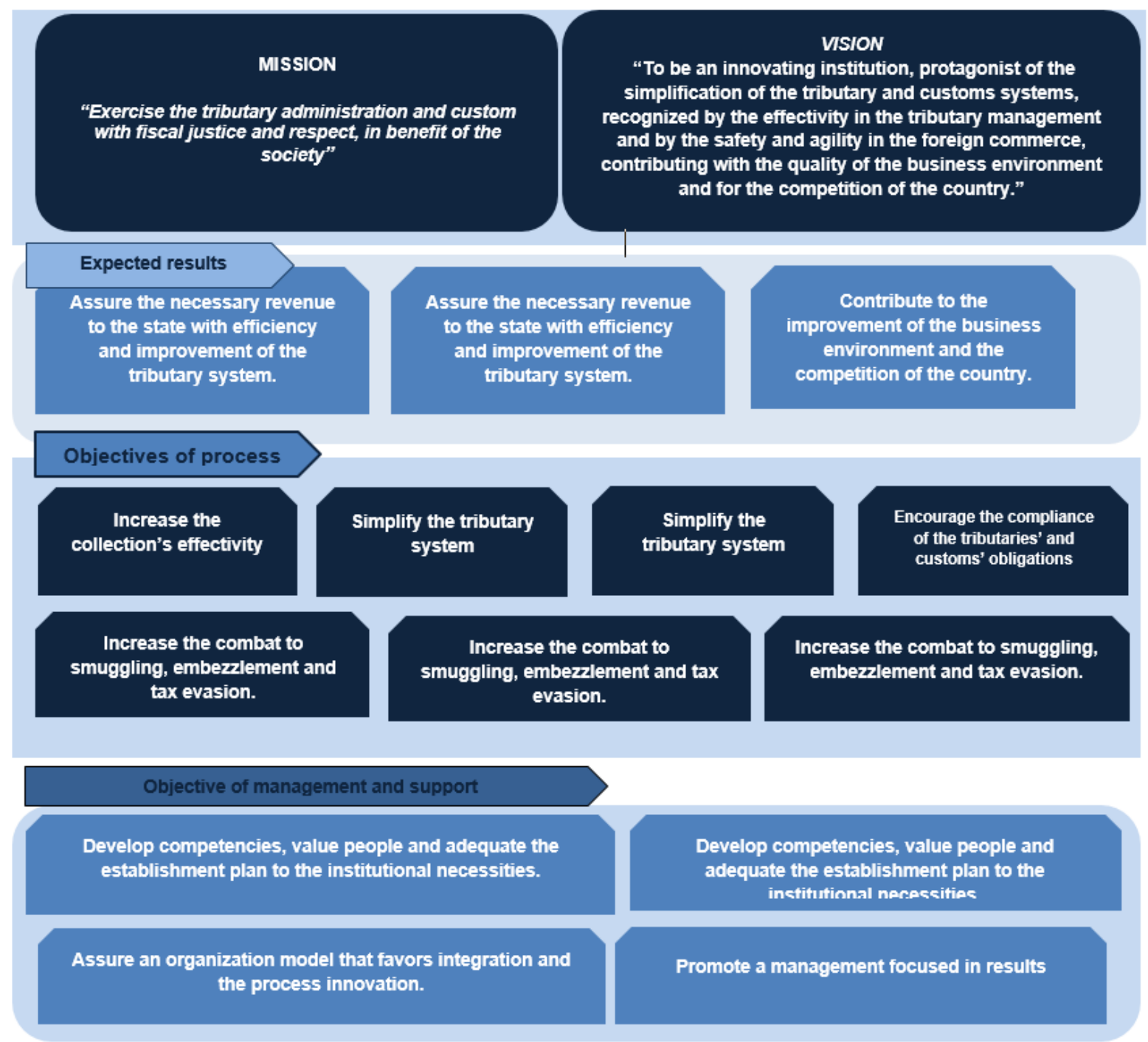

Figure 2. The Strategic Planning of RFB

Source: Brazilian Federal Revenue (RFB, 2017).

In the RFB, the strategic management is, already, a reality, and it has as responsible the Strategic Planning Department, Organization and Institutional Evaluation

The RFB developed its strategic planning based in the construction of a vision from the future. This construction is based in the exploration of future scenes simulated by means of techniques, applied in the strategic planning area of the organization, in other words, to the manager's staff that works with strategy and tactics. That process involves meetings to discuss strategies that provide support elements to the participants of those events, in a way of allow, though the interaction and discussion of important topics, the future scenarios (RFB: COPAV, 2017).

\subsection{The Strategic Planning in Similar Organizations from Different Countries}

This section is about, beside the elements of strategic planning, historic and recently data 
about the tax administration from other countries. The limitation of the dada of those organizations is caused by the difficulty to access them. In this research were used the dada available in the officially websites pages of this organizations. The research focus is in the tax administration of Brazil and USA, Argentina, Uruguay, Paraguay, Chile and Canada.

\subsubsection{The Tributary Administration in the USA}

The tax administration of the USA is performed by the IRF - Internal Revenue Service. According to the data of the website page of this organ, the IRS is organized to perform the responsibilities of the secretary of the Treasury of that country, under the section 7801 of the Federal Revenue Code. The origin of the IRS is linked to the Civil War when the president Lincoln and the Congress, in 1862, funded the commissioner of the intern Revenue and stablished an income tax to pay the expenses of the war. The act of the Re-structure and Reform of the IRS from 1998 made the reorganization and modernization of the IRS in almost half century. The IRS reorganized to be similar enough from the private sector of organization around the clients with similar necessities (IRS, 2017).

Still according to dates mentioned in the web page, the IRS is an organ of the American Treasury Department and one of the most efficient fiscal administrations of the world. In the fiscal year of 2015, the IRS collected almost US \$3,3 trillion dollars of revenue and process almost 250 million of fiscal declaration, and it had expend only 35 cent for each US \$100 that collected in that fiscal year (IRS, 2017). The IRS' strategic planning from the period of 2014 to 2017, stablished the objectives and goals of the agency for the next four year.

\subsubsection{The Tributary Administration of Argentina}

The tax administration from Argentina is performed by the AFIP - Adminstración Federal de Ingresos Públicos. According to the web page on the internet (AFIP, 2017) it was possible to identify from the lecture of the strategic planning from 2011 to 2015 that the origin of the AFIP integrates three organs: DGI - Dirección General Impositiva, ANA - Adminstración Nacional de Aduanas e DNRP - Dirección Nacional and Recaudación Previsional. The integration began in 1997 and its process of consolidation turns into a strategic planning in 2007-2010.

The AFIP mad their operational action in three specialized areas: The DGA - Dirección General de Aduanas, the DGI - Dirección General Impositiva and the DGRSS - Dirección General de los Recursos de la Seguridad Social (AFIP, 2015). According to the Management Planning of the AFIP 2017, because of the private circumstances, that involves the development of the AFIP in 2016, it was not possible to formulate the new Strategic Planning (AFIP, 2017). Because of this fact, it will be analyzed the Strategic Planning from 2011 to 2015 , which were used to compare the objective of this research.

\subsubsection{The Tributary Administration of Paraguay}

The tax administration from the Paraguay is made by the SET - Subsecretaría de Estado de Tributación, responsible for the application and administration of the legal coordination related to the tax. It will orient, guide and administrate the tax management and fiscal 
stablished in the act $\mathrm{n}^{\circ} 125 / 91$ that stablishes the new tax regime and its reforms; the act $\mathrm{n}^{\mathbf{0}}$ 2421/04 of administrative reorganization and the fiscal adjustment and the ones that will replace it in the future, such as the establishment of rules and system of the duty's administration, taxes and contributions of its position, and in what correspond to the liquidation, examination, inspection, revenue, implementation of penalty and the process of resources (SET, 2017). In this research the Strategic Planning from SET was used from 2014 to 2018 .

\subsubsection{The Tributary Administration of Uruguay}

In Uruguay the tax administration is performed by the DGI - Dirección General Impositiva. Integrating the Central Administration and subordinate to the Ministry of Economics and Finances, the DGI is the Executive Unit responsible for the collection of intern tax and effective application of the rules that are in order of that (DGI, 2015).

Besides, of its traditional function as a collector, the DGI performs another important function that is the realization and the control of the concession of benefits and subsidy stablished by the Central Government, such as mechanism of promotion and/or assistance to different sectors of the economic activity. Besides that, the organization performed an important function to the process of the implementation of the law of financial inclusion 19.210 of April $29^{\text {th }}$ of 2014 , being responsible for performing the benefit of the reduction of the IVA through the concession of the fiscal credit (DGI, 2015). In this research was used the strategic planning of the DGI from the period of 2015 to 2019.

\subsubsection{The Tributary Administration of Chile}

In Chile, the tax administration is performed by the SII - Servicio de Impuestos Internos. The Chilean tax administration was created in 1902, with the founded of the "Tax administration about the alcohols". In 2001, was stablished the Act 12.738 "Regulation against the tax evasion", that modified many laws, which include the laws of organization of Service of Internal Tax, Customs and Treasury (SII, 2017).

The strategic planning of SII aim to reinforce the central objective of the organization, focus in the compliance of the tax to ensure the resources that the country's needs for its development in fair conditions. The Manager Model of Tax Compliance is concerned to determine in a specific way, the characteristics of the contributors' behavior. That way, it is applied an action that has proportional risk and damage that can be caused to the States resources. Pursuit the implementation of actions that has the objective of facilitates and simplifies the tax process to the contributors. The four strategic areas defined are the inclusion of the Manager Model of the Tax Compliance, the implementation of the new Assistance to the Contributor Model, the Tax Reform and the implantation of the Management Process Model (SII, 2017).

\subsubsection{The Tributary Administration of Canada}

In Canada, the tax administration is performed by the CRA - Canada Revenue Agency. The CRA is responsible for the administration of fiscal programs, as the provision of economic 
and social benefits. It also manages some provincial and territorial fiscal programs. The CRA further the compliance of the legislation and fiscal regulations from Canada and it has an important function in the economic and social welfare of the Canadians (CRA, 2017).

The tax system of the Canadians is based in the self-evaluation and voluntary compliance. To this system works, it must be fair and noticed as well. The contributors are likely to follow the rules when they are treated with fair and when they have information so they know about their rights and duties. The CRA has the objective of protect the integrity of the tax system, performing their tax obligations for everyone. Besides, they guarantee that Canadians, especially the indigenous, the aged, the poor and the deficient people received their benefits (CRA, 2017).

The CRA shows a volume of US \$ 485 billion in duty and in taxes processed in the period of 2015 - 2016, and the planned expenses of the organ from 2017 to 2018 is in order of US $\$ 4,2$ billion, which means that the cost for every US $\$ 100$ is of US $\$ 0,86$. Besides, in this period it was 31 million of tax declaration, US $\$ 28,6$ billion of benefits paid to 12,8 million beneficiaries (CRA, 2017). In this research it was used the strategic planning of CRA for the period of 2017- 2018 to 2019-2020.

\section{Comparative of the Strategic Plans}

This part of the research shows a comparison of the strategic planning of the organizations researched, trying to demonstrate through the comparisons the relations and differences in the strategy of each one of them, at the same time is analyzed of some elements, showing the relevant aspects.

\subsection{The Mission}

Through the material gotten about the organizations, it was created a comparative box with the purpose of analyze the fundamental elements of the strategic planning from the organizations, with the objective of verify their similarity and differences. The Figure 3 shows a picture of the mission, vision of the future and values of those organizations.

\begin{tabular}{|c|c|c|c|}
\hline INSTITUTION & MISSION & VISION & VALUES \\
\hline RFB & $\begin{array}{l}\text { Exercise the tributary } \\
\text { administration and customs } \\
\text { with fiscal justice and respect } \\
\text { to the citizen, in benefit of the } \\
\text { society. }\end{array}$ & $\begin{array}{l}\text { Being an innovating institution, protagonist in the } \\
\text { simplification of the tributary and duties system, } \\
\text { recognized for the effectivity tributary } \\
\text { management and for the safety and agility in the } \\
\text { foreign trade, increasing the quality of the business } \\
\text { field and the country's competitively. }\end{array}$ & $\begin{array}{l}\text { - } \text { Respect to the } \\
\text { citizen } \\
\text { - } \text { Integrity } \\
\text { - } \text { Loyalty to the } \\
\text { institution } \\
\text { - } \quad \text { Pegality } \\
\text { - Trofessionalism } \\
\text { Transparency }\end{array}$ \\
\hline IRS & $\begin{array}{l}\text { Provides to the USA } \\
\text { contributors a service of high } \\
\text { quality, helping them to } \\
\text { understand their tributaries }\end{array}$ & $\begin{array}{l}\text { Defend the integrity of the tributary system of our } \\
\text { nation and preserve the confidence from the public } \\
\text { through the talented work, innovating } \\
\text { Technologies and collaborative partnership. }\end{array}$ & $\begin{array}{l}\text { - Honesty and } \\
\text { integrity } \\
\text { - Respect } \\
\text { - Continuous }\end{array}$ \\
\hline
\end{tabular}




\begin{tabular}{|c|c|c|c|}
\hline INSTITUTION & MISSION & VISION & VALUES \\
\hline & $\begin{array}{l}\text { responsibilities and to apply } \\
\text { the law with integrity and } \\
\text { justice to all. }\end{array}$ & & $\begin{array}{ll} & \text { improvement } \\
\text { - } & \text { Inclusion } \\
\text { - } & \text { Openness and } \\
\text { collaboration } \\
\text { - Personal } \\
\text { responsibility }\end{array}$ \\
\hline AFIP & $\begin{array}{l}\text { Administrate and apply, } \\
\text { perception, control and } \\
\text { inspection of the nationals } \\
\text { tributes of social security } \\
\text { resources and the activities } \\
\text { related to the foreign } \\
\text { commerce; promoting the } \\
\text { voluntary compliment, the } \\
\text { economy improvement and the } \\
\text { social inclusion. }\end{array}$ & $\begin{array}{l}\text { The AFIP will be consolidated as an excellence } \\
\text { institution, oriented to generate an fiscal a } \\
\text { favorable climate to the formal economy, the } \\
\text { employee record and the safety in the foreign } \\
\text { commerce. }\end{array}$ & $\begin{array}{l}\text { - } \\
\text { - } \quad \text { Integrity } \\
\text { - } \quad \text { Vocation to } \\
\text { - } \quad \text { Profice } \\
\text { - } \quad \text { Proactivity } \\
\text { - Social } \\
\text { - }\end{array}$ \\
\hline SET & $\begin{array}{l}\text { Collect taxes with integrity, } \\
\text { efficacy and transparency, } \\
\text { facilitating the compliance of } \\
\text { the contributor's obligation } \\
\text { through the constant } \\
\text { innovation of services and an } \\
\text { excellent management that } \\
\text { aim to become the citizens } \\
\text { responsible and compromised } \\
\text { with the country. }\end{array}$ & $\begin{array}{l}\text { Being one of the fiscal institutions more favorable } \\
\text { and efficient from the Latina America. }\end{array}$ & $\begin{array}{ll}\text { - } & \text { Integrity } \\
\text { - } & \text { Responsibility } \\
\text { - } & \text { Transparency } \\
\text { - } & \text { Efficiency } \\
\text { - } & \text { Vocation to } \\
\text { - } & \text { Justice } \\
\text { - }\end{array}$ \\
\hline DGI & $\begin{array}{l}\text { Collect the taxes of statue } \\
\text { resources of the tributary } \\
\text { system through the effective } \\
\text { application of rules that } \\
\text { supported it, promoting the } \\
\text { voluntary compliment, and } \\
\text { respect of peoples right, acting } \\
\text { with integrity, efficiency and } \\
\text { professionalism with the } \\
\text { objective of offering a good }\end{array}$ & $\begin{array}{l}\text { Being recognized as an Tributary Administration, } \\
\text { that with high levels of quality provides } \\
\text { transparency service, obtain resources that } \\
\text { contribute to the country development, the social } \\
\text { justice and the well-being of their habitants. The } \\
\text { organization and its employees are respected for } \\
\text { their compromising to the values and consecrated } \\
\text { to the mission - institutional vision and its Conduct } \\
\text { and Ethical Code. }\end{array}$ & $\begin{array}{l}\text { - } \text { Respect } \\
\text { - } \quad \text { Integrity } \\
\text { - } \quad \text { Prficiency } \\
\text { - } \quad \text { Quality of service } \\
\text { - Transparece }\end{array}$ \\
\hline
\end{tabular}




\begin{tabular}{|c|c|c|c|}
\hline \multirow[t]{2}{*}{ INSTITUTION } & MISSION & VISION & VALUES \\
\hline & service to the society. & & $\begin{array}{l}\text { *Obtained from the } \\
\text { mission and vision. }\end{array}$ \\
\hline SII & $\begin{array}{l}\text { Assure that each contributor is } \\
\text { going to compliance his or her } \\
\text { fiscal obligation. Applying } \\
\text { and inspecting the intern } \\
\text { tributes in an efficiently way, } \\
\text { with restrict conformity with } \\
\text { the legislation, trying to } \\
\text { facilitate the conformity, } \\
\text { through the principle of } \\
\text { probity, equity and } \\
\text { transparency, in an } \\
\text { environment of working that } \\
\text { provide the integral } \\
\text { development of the public } \\
\text { servants with the intention of } \\
\text { reach an excellent } \\
\text { performance that contributed } \\
\text { to the countries progress. }\end{array}$ & $\begin{array}{l}\text { We would be a public institution recognized in a } \\
\text { national and international level by: } \\
\text { Efficacy, efficiency, and autonomy in } \\
\text { its institutional manager. } \\
\quad \text { Increase and improve the evasion and } \\
\text { elision control, keeping them in their } \\
\text { minimal record and maximize the } \\
\text { voluntary compliances. } \\
\quad \text { Equity, probity and transparency in } \\
\text { the performance of its public role. } \\
\text { Provide technological and innovating } \\
\text { solutions for the monitoring work. } \\
\text { Employees prepared and compromised } \\
\text { with the countries progress. }\end{array}$ & $\begin{array}{l}>\text { Probity } \\
>\text { Equity } \\
>\text { Excellence } \\
>\text { Compromising } \\
>\text { Transparency } \\
>\text { Respect }\end{array}$ \\
\hline CRA & $\begin{array}{l}\text { Administrate tributes, benefits } \\
\text { and programs related and } \\
\text { assure the compliance of the } \\
\text { Canada's governs, } \\
\text { contributing to the Canadians' } \\
\text { economic and social } \\
\text { well-being }\end{array}$ & $\begin{array}{l}\text { The CRA is a safe model of administration of taxes } \\
\text { and benefits, proving an incomparable service and } \\
\text { value for their clients and offering excellent } \\
\text { opportunities of career for their employees. }\end{array}$ & $\begin{array}{l}\text { The employees of CRA } \\
\text { perform with integrity, } \\
\text { respect and } \\
\text { professionalism } \\
\text { *(Strategic priorities: } \\
\text { People) }\end{array}$ \\
\hline
\end{tabular}

Figure 3. Comparative of Mission, Vision and Values1

Source: Created by the author (2017).

The mission of the organization is explained with reason of its existence. Why exist, what does it do and what does it intend to present? The principal purpose of the tax administration is to promote necessary resources to the State, attending the necessities of the public politician. However, it is noted that from all the explored missions of this research, just two organizations use the expression of collect as a verb in the center of their mission, which are 
the SET and the DGI.

Some elements inserted in the missions have a complex and an expanding connotation and meaning. It is not intending to explore those elements, because of that their meaning would get in other areas of science, as sociology and lawyer for an example. Here it is made a reference to the legal terms of the fiscal justice, justice for everyone, respect to the rights and equity. Anyway, those elements bring discussions as the concept of the fiscal justice, for an example. In developed countries, we had a fiscal justice that could be identify as unfear because of the excess of tax above the expenditure and not too committed to the tax above the property and income from the richest. In this way, a deep intervention capable of performing changes in what can be said as an unfear tax system, the mission of the tax administration through this context can be utopic.

In other aspect, the missions detailed in the Figure 3 point out other element related to the organization context, presenting flexibility and maybe an acceptance that insert the tax rules does not mean it acceptance, comprehension and its compliance. Therefore, it found expressions as in the Figure 4.

It is not about the transference of attributions to the contributor. The meaning of the expressions is related to the idea that the mission of the tax administration is to offer an excellent service to the citizen or contributor and an active fiscal education, providing knowledge and the acquisition of competencies by the required in face of the Treasury, and, still, creating rules and developing technologies that facilitate the voluntary compliance of the tax obligation though the managed.

\begin{tabular}{|ll|}
\hline - & Providing high quality service to contributors \\
\hline - & Help the contributor to understand and comply their tributary responsibilities \\
\hline - & Promote the voluntary compliance \\
\hline - & Make the compliance of the obligation easier to the contributor \\
\hline - & Become each citizen a responsible contributor and compromised with the country \\
\hline - & Assure the compliance of the fiscal obligation by the contributor \\
\hline - & Making the conformity with the legislation current \\
\hline - & Assure the compliance \\
\hline
\end{tabular}

Figure 4. Elements of mission

Source: Created by the author (2017).

From this finding, one reflection must be raised, once that the progress and the modernity of the contemporaneous society does not exclude an efficiently fiscal policy education. The mission does not reflect in this worry. However, pay the tax to the State is an obligation and a citizen act, which the fiscal conscience must be permanent, developed as a culture element, and of participation in maintains of the State, how required and created by the society. Therefore, it is mission of the tax administration the growth, the straightening of the citizen 
culture; elements that only the fiscal education can be capable of create and keep.

\subsection{The Vision of Future}

The vision of future reveal how the organization imagine the trajectory of a determine time cycle, what the picture that is intent to construct in this timeless horizon. Therefore, it can be realized how it is considered today and how it is intended to be recognized in the future.

It is noted that the worry about the simplification of the dates system, while in other aspects they keep the preservation of its integrity, which sounds antagonistic, however it must concern that the context of each administration. It is can be noticed in the case of RFB, intending to be an institution that highlight the innovation and the simplicity of the tax and treasury system, in one side, and in other, the IRS appoint that there is a worry about the defense of the integrity of the tax system and preservation of the confidence of the public.

This scene shows insecurity for two distinct contexts, in other way a tax administration of a growing country, trying to turn its tax system simpler and newer, denoting the idea that if this system needs adjusts that helps its improvement. As far as in another way, maybe because of a mature tax system it defends the preservation of it integrity and the society confidence in this system.

The economic context shows influence in their future vision, which can be seen in the examples of the IRS and CRA, situated in countries that are considered developed, linked with the maintenance or preservation of the confidence in those organizations, fruit of a tributary system that express to be consolidated and accepted in their respective society. Add that to the fact of the worry with people, reflected to the vision of the future of those organizations, with the strength of a talented work and the worry in offer opportunities of excellent careers to their employees, respectively.

In general, it is common to the most visions of future of the tributary administrations the worry about the innovation and about the technological solutions, besides that, there are the desire of the institution and of their contributors of being recognized and respected, in a context related to the ethical conduct and of the legal standards.

The $5^{\text {th }}$ Figure shows a brief view of the organizations' vision about the future.

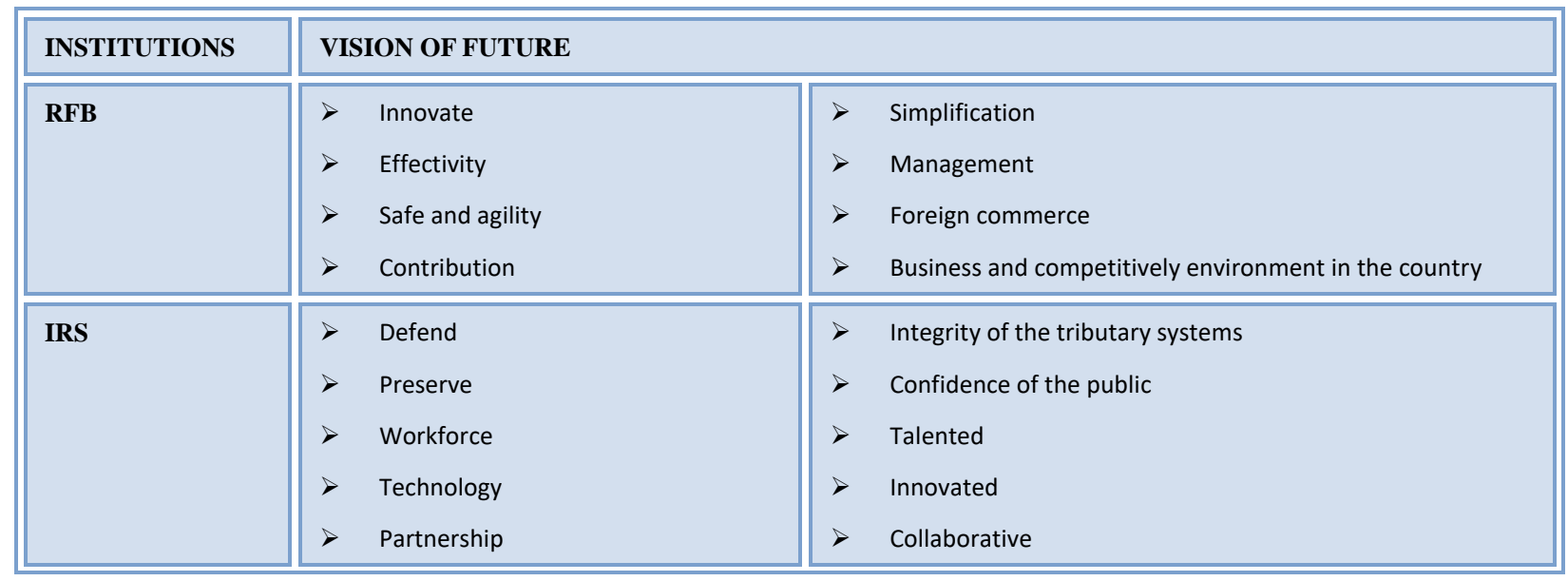




\section{Macrothink}

Journal of Public Administration and Governance

ISSN 2161-7104

2018, Vol. 8, No. 3

\begin{tabular}{|c|c|c|c|c|}
\hline INSTITUTIONS & \multicolumn{4}{|c|}{ VISION OF FUTURE } \\
\hline AFIP & & $\begin{array}{l}\text { Consolidate } \\
\text { Orient }\end{array}$ & $>$ & $\begin{array}{l}\text { Excellence } \\
\text { Create a tax environment favorable to the formal } \\
\text { economy, the employment record and the safety in the } \\
\text { foreign commerce }\end{array}$ \\
\hline SET & $>$ & $\mathrm{Be}$ & $>$ & Innovated and efficiently \\
\hline DGI & $>$ & $\begin{array}{l}\text { Be recognized } \\
\text { Resource acquisition } \\
\text { Be (organization and employees } \\
\text { respected) }\end{array}$ & $\begin{array}{l}> \\
> \\
> \\
> \\
> \\
>\end{array}$ & $\begin{array}{l}\text { High performance } \\
\text { Service of quality } \\
\text { Transparency } \\
\text { Social justice } \\
\text { Well-being } \\
\text { Country improvement } \\
\text { Compromising, values and ethic }\end{array}$ \\
\hline SII & $>$ & $\begin{array}{l}\text { Be nationally and internationally } \\
\text { recognized }\end{array}$ & $\begin{array}{l}> \\
> \\
> \\
> \\
>\end{array}$ & $\begin{array}{l}\text { Efficiency and autonomy of the management } \\
\text { Elision and evasion control } \\
\text { Increase the voluntary compliance } \\
\text { Equity, probity and transparency } \\
\text { Technological solutions } \\
\text { Trained and committed staff }\end{array}$ \\
\hline CRA & $\begin{array}{l}> \\
>\end{array}$ & $\begin{array}{l}\text { Administration model } \\
\text { Trustable } \\
\text { Propose } \\
\text { Offer }\end{array}$ & $\begin{array}{l}> \\
>\end{array}$ & $\begin{array}{l}\text { Taxes and benefits } \\
\text { Incomparable service } \\
\text { Excellent opportunities of careers for the employees }\end{array}$ \\
\hline
\end{tabular}

Figure 5. Comparative of Vision of Future2

Source: Created by the author (2017)

\subsection{The Values}

It is noted that the information obtained of these elements show common points and some divergence when it is compared to the organizations value. However, it is observed some similarities such as some interesting differences in the structure of this strategic benchmark of the organizations. The $6^{\text {th }}$ Figure shows the composition of these elements. 


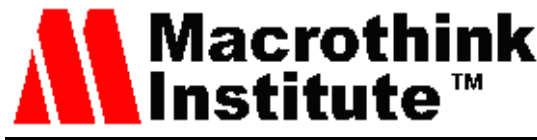

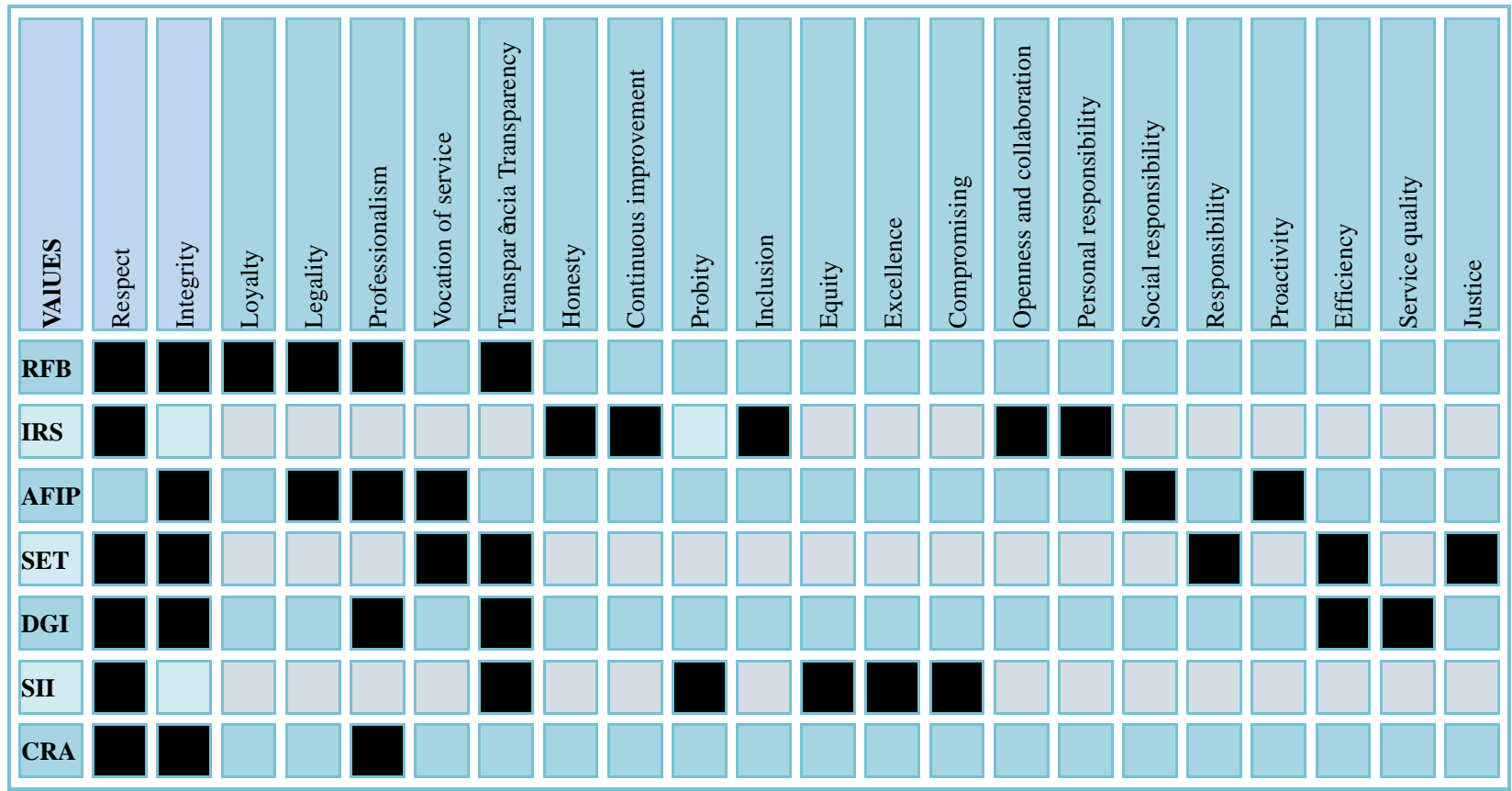

Figure 6. Values - Tributaries Administrations

Source: Created by the author (2017)

The terminology used in the description of values by the organizations has elements that could be considered equal or at least, similar, such as the terms Honesty, Probity and Integrity, which are present in all organizations from the $5^{\text {th }}$ Figure. It could be considered similar terms the words Professionalism and Service Vocation. Therefore, those tributary administration are very similar in terms of orientation for a posture that represent the institutions' and their member's integrity, concerning that their attitudes reveal a professional and responsible posture.

The values honesty, probity and integrity have a close relation in reason of obtaining confidence of the intern and extern society, transmitting the concept of honesty and ethical conduct in the organizations actions. Therefore, the service vocation is oriented through the idea of offering an appropriated treatment to the citizen, satisfying their necessities in relation to the revenue, in reason of the compliance of the organization, certainly it require the appropriate professionalism to deal with the delicate tributary issues, resulting in a good service to the citizen who needs their service (AFIP, 2015, CRA, 2017b, DGI, 2015; IRS, 2017, SET, 2017; SII, 2017b, RFB, 2017).

The $5^{\text {th }}$ Figure also shows that some organizations values are common to the biggest national tributary administration, as in the case of terms Respect, Integrity, Professionalism and Transparency. In turn, some terms, which mean values do not appear so frequently. These are the cases of Loyalty, Legacy, Inclusion, Openness and Cooperation, Compromise, Continual Improvement, Efficiency, Proactivity, Personal Responsibility, Social Responsibility, Responsibility, Quality of Services and Justice.

Among those values defended in the RFB strategic reference are loyalty with the institution and legacy. The Definition of the values stablished in the strategic planning of the 
organization is not stablished for Decree RFB 1749/2016, which prove the strategy, the strategy indicators and the institutional strategic projects from RFB to the period of 2016 to 2019 (RFB, 2016). Through the context of those, it is supposed that the loyalty with the institution shows the respect to the ethical conduct, showing that the professionals of the organization are loyal to them, preserving in their respective attributions the appropriate service, as the legal rules and the conduct code, from the information that are available in reason of it service. The legality is concerned to the respect to the normative framework that organize the performance of the organization and it members.

The values continuous improvement, inclusion, openness and collaboration and personal responsibility are related to the strategic planning of IRS. The definitions of those formulated in that document inform that in terms of continuous improvement, the attempt to perform their best, at same time that embrace the change with the purpose of improve the future; the inclusion propose to obligate the diversity of knowledge, experiences and perspectives; openness and collaboration seam the share of information and collaboration, in the meaning of valuation of teamwork; and the personal responsibility correspond to the fact of assume responsibility for their action and decision and to the purpose of learning and growing though mistakes and achievements of the company (IRS, 2017). The value of the personal responsibility from the IRS corresponds to the same value and responsibility of the SET, because it corresponds to the transparency of the actions and to the recognition and acceptance of the consequences of their actions (IRS, 2017; SET, 2014).

The values of compromising, equity, excellence, social responsibility, proactivity, efficiency, quality of service and justice, that compromising correspond to the resolution of purposes that aim to the use of the competences of the organization to perform their challenges and objectives. Equity and justice correspond to the notion of giving the adequate treatment, without discrimination, acting impartially, so everybody has the correct treatment as their rights. However, excellence, efficiency and quality of service is related to the development of functions made in a great way, searching for innovation, performing a service of quality, efficiently and effectively, that contribute to the country improvement (AFIP, 2015; DGI, 2015; SET, 2014; SII, 2017b).

Social responsibility and proactivity are the constant values of the strategic planning from AFIP. In the available documents, it was not possible to identify the concept attributed to them. When the theme is explored, it is deduced that the social responsibility has connotation of the adoption of postures and actions in a voluntary way, aiming the well-being of the organization's collaborators and the society. It can embrace the aspect of social inclusion that corresponds to a strategic concern of the organization, in order to defend the formal employment of the citizen and combat the evasion of social security revenue. Referent to the proactivity, what it is noted of strategic planning, about this term is that it is related to the idea of anticipation or to the capacity of acting to influence in specific situations, keep relation with the proactive participation in normative questions, legislatives, that have relation to the organization's activities (AFIP, 2015). 


\subsection{Strategic Objectives}

This part of the research has the objective of comparing the strategic objectives of the organizations researched. In this comparison, the strategic objectives are in the $7^{\text {th }}$ Figure and it shows in a summarized way or as a key term to its identification. It is not present all the objectives related in the strategic plans, because it would extend this comparison to much. The intention is to show the similarities and the differences in the respective plans, without purposing any connotation of evaluation, if it is more or less adequate, because it is not the purpose of the research. Actually, the adequacy of each strategic objective, adjusts, inclusion and exclusion are a pertinent evaluation of each organization and happen through evaluation and supervision of it planning along the period of execution. It is necessary to have in mind that strategic indicators follow the strategic objectives.

\begin{tabular}{|c|c|c|c|c|c|c|c|}
\hline STRATEGIC OBJECTIVES & RFB & IRS & AFIP & SET & DGI & SII & CRA \\
\hline \multicolumn{8}{|l|}{ Of revenue } \\
\hline \multicolumn{8}{|l|}{ Simplification } \\
\hline \multicolumn{8}{|l|}{ Foreign commerce } \\
\hline \multicolumn{8}{|l|}{ Charge } \\
\hline \multicolumn{8}{|l|}{ Inspection } \\
\hline \multicolumn{8}{|l|}{ Management and risk analysis } \\
\hline \multicolumn{8}{|l|}{ Stimulated the compliance } \\
\hline \multicolumn{8}{|l|}{ Litigation reductions } \\
\hline \multicolumn{8}{|l|}{ People } \\
\hline \multicolumn{8}{|l|}{ Resource } \\
\hline \multicolumn{8}{|l|}{ Organization model } \\
\hline \multicolumn{8}{|l|}{ Management to results } \\
\hline \multicolumn{8}{|l|}{ Invest in the workforce } \\
\hline \multicolumn{8}{|c|}{ Provide assistance in a multi-channel platform } \\
\hline \multicolumn{8}{|c|}{ Safety of people and of the installations } \\
\hline \multicolumn{8}{|c|}{ Investment in innovation and in Technologies } \\
\hline \multicolumn{8}{|l|}{ High quality services } \\
\hline \multicolumn{8}{|l|}{ Combat to fraud } \\
\hline \multicolumn{8}{|c|}{ Reduce the volume of contribution } \\
\hline \multicolumn{8}{|c|}{ Relationship with the tributary community } \\
\hline \multicolumn{8}{|c|}{ Partnership with the professional community } \\
\hline \multicolumn{8}{|c|}{ Become the primary control stronger } \\
\hline Develop a quality process & & & & & & & \\
\hline
\end{tabular}




\begin{tabular}{|c|c|c|c|c|c|c|c|}
\hline STRATEGIC OBJECTIVES & RFB & IRS & AFIP & SET & DGI & SII & CRA \\
\hline \multicolumn{8}{|l|}{ Promote the social inclusion } \\
\hline \multicolumn{8}{|l|}{ Strategic Alliance } \\
\hline \multicolumn{8}{|c|}{ Take part in the normative definitions } \\
\hline \multicolumn{8}{|c|}{ Minimize the cost of the revenue acquisition } \\
\hline \multicolumn{8}{|l|}{ Acceptance of the social taxes } \\
\hline \multicolumn{8}{|l|}{ Integral vision of the process } \\
\hline \multicolumn{8}{|l|}{ Improvement of the register } \\
\hline \multicolumn{8}{|l|}{ Organization communication } \\
\hline \multicolumn{8}{|l|}{ Visibility in the institutional acts } \\
\hline \multicolumn{8}{|c|}{ Management of the contributor experience } \\
\hline \multicolumn{8}{|l|}{ Ethical straightening } \\
\hline \multicolumn{8}{|c|}{$\begin{array}{l}\text { Compromising with the development and quality } \\
\text { of professional life }\end{array}$} \\
\hline \multicolumn{8}{|c|}{ Integrity and safety of the system } \\
\hline \multicolumn{8}{|l|}{ Social Benefits } \\
\hline International partnerships & & & & & & & \\
\hline
\end{tabular}

Figure 7. Comparative of strategic objectives

Source: Created by the author (2017).

The $7^{\text {th }}$ Figure shows that the strategic plans from the researched organization have lot of similarities that define their strategic objectives. This becomes evident when it is noted that the actions of inspection perform an essential objective of the tributary administration, because through the objectives it is reached or inducted to the reach of other objectives, directly or indirectly influenced by it. It is the case, for an example, of the revenue that suffers direct influence, as the contributors realize the risk of inspection actions; and the voluntary compliment of the tributaries obligations happens, pretty much, because of it.

The strategic objective of getting from their contributors, the voluntary compliment of the fiscal obligation is also common to the organization, what justify the existence of objectives as the incentive to the voluntary compliment, the simplification of the rules and the procedures to its compliment and investment in innovation and technology.

The strategic objective of the litigation seems expressly in the planning of RFB. Obviously, that in the others organization there is this process of working, related to the solution in the administrative area of fiscal questions. However, when this objective is expressed in an explicit way, the RFB shows that there is an expressive volume of fiscal litigation in discussion in the administrative area and that there is a necessity of acting in an effective way in its reduction, as in the prevention to avoid occurrence. 
The objectives related to organization model are present in the strategic plans of RFB, SET and DGI. Therefore, there are in this area, adjusts in the organization structure that can be promote, aiming adequacies. That fact, actually, in this year of 2017, was materialized in RFB, which is passing through adjustments in their Internal Regulation.

The offer of multiplies areas to self-service, acquisition of orientation to the contributors, it is shown in an explicitly way in the strategic plans of the IRS and the DGI, showing concern with the service to the contributor. However, this way of service and assistance is certainty common to the other organizations. The creation of one strategic objective, conduct that the monitoring indicators of that objective being stipulated. The lack of this element in the planning can indicate that the organization is working well in this point. On the other hand, there is the risk of neglecting this aspect. The same is possible to consider in relation to the objective of investing in innovation and technology.

In relation to the IRS, the strategic objective related to the safety of people and the installations seams to indict a specific element in the context of that country. Others strategic objectives do not have this peculiar characteristic, because its nature is common. However, represent expressly just in the planning of IRS (once again it is observed that this does not mean its existence in the other organizations), as in the case of the objectives of offering service of high quality, reduce the volume of compliment to the contributor, relating with the tributary community and cooperation to the professional community.

Others strategic objectives that must be mentioned because of its peculiarity are: promote the social inclusion, present in the AFIP and CRA, aspect related to the management of social benefits, in the CRA case, and the concern to the formalization of work, in the case of AFIP. Another specific objective of the DGI is the strategy to minimize the cost of acquisition, keeping a close relation with the administrative efficiency and it is related, aspects as the simplification of rules and procedures with the social acceptance of the taxes. Something obviously common to the others organization, expressing in the DGI in its strategic planning and that require constant actions of fiscal education, and also of legitimation of state action and transparency of the public expenses.

The SII also shows some specifics strategic objectives, as in the case of the visibility of the institutional act, the managing of the experience of the contributor and the strengthening of the ethic. Of course, that the visibility of the institutional act that is searched is a promotion of good image, the managing of the experience of contributor has relation with the concern in a service of quality, and the strengthening of the ethic transmit a perception that the organization has an objective, that besides of being common to the others, needs to be strengthened in the organization.

The CRA shows some specifics objectives as the integrity and the safety of the tributary system, factor related to confidence of the citizens in the organization; the concern with social benefits, factor related to a specific activity of that organization; and with international partners, factor related to the collaboration and to the combat to fiscal evasion. This last, expressed in the CRA planning, it is common, considering that the tributary system of the countries analyzed are not closed, and as far as possible, share information to other countries 
or international organs.

\section{Final Considerations}

The strategic planning provides to the organization self-assertion, when identifies and propose a future horizon and a way of reaching it. Therefore, the components of the strategic planning mission, vision, objectives of long-term, scenes and operational plans identify the organization profile (Fischmann \& Almeida, 1991). In this respect, considering that the strategic planning aim to prepare for the future, in an inclusive and systematic way, and provides agility in the decisions making, according to a sequence of actions to the reach of objectives and goals.

When exploring the missions defined by the tributary administration analyzed, some elements call the attention and refer to a new conception adopted in the area, with the idea of a greater flexibility and of recognition that the imposition of tributary rules does not mean its necessary acceptance, its comprehension and compliance. Search, in this context, an encouragement to the voluntary compliance of the tributary obligations by the administered, providing services of high quality, simplification of obligations, turn the conformity easier. Help and orientation to the contributors, what shows a tendency of aligning in a position of improvement and modernity, in conformity to the possibilities and realities of the actual society, equipped with advanced technology available, and a big quantity of people and organization. Besides that, in developed countries, people worry no just with their rights, but with their duly and with the proactivity in the monitoring of resource of public budget.

In terms of vision of future, it was noted to be common to the tributaries administrations the concern to innovation and technological solutions, besides of the recognition and respectability of the institution and in its collaborators, in a context related to the ethical conduct and legal standard. The economic context that insert a tributary administration shows influence of their vision of future from the examples of IRS and CRA, situated in countries considered developed, when analyze the vision of future linked to the maintenance or preservation of the confidence of the society in those organizations, fruit of a tributary system consolidated and accepted in their respective society. Add that to the fact of the concerning to people, reflected in the vision of future of those organizations, as the force of a talented work and the concern in offering excellent opportunities of career to their employees, respectively.

In respect of values, it was noted that the tributaries administration are similar in what concern to the orientation to the integrity of the institution and their members, because that the values honesty, probity and integrity keep a close relation in the meaning of acquisition of society intern and extern confidence, transmitting the concept of honesty and ethical conduct in the actions of organizations. Also showing a concern in terms of performing an alignment with a professional posture and specialized in the treat of their attributions. Other commons point are the values as respect and transparency.

In terms of objectives, the strategic plans of the organizations searched show similarities, as in the case of the objective related to the action of inspection, that perform influence above others as collecting, the voluntary compliment of the obligations and the investments in 
innovation and technologies. Still, the objectives of the elevation of the collecting or it maximization are also common, but do not cons explicit in all plans, although the tributary administrations understand that there is a difference between what is collected and what could be collected. Besides, objectives related to the personal managing and resources, the results management and simplification of the system are also common.

Before the exposed, certificate that the objective of the work, of comparing the strategic planning of the Brazilian Federal Revenue with similar institutions from other countries was reached and provides to know the similarities and differences among the organizations researched. In relation to the limitations of the research, related to the availability of information in respect to the strategic plans of the organization, it is possible to assure that the fact of the source-researched reveal a wealth of information minimizing the limitation.

Finally, in relation to the contributions of the study, it is assured the possibility of increase the knowledge about the tributary administration from the researched countries, knowledge that, that can be extend to other organizations because of its similarities in this important segment of public administration.

However, some consideration, in expression of contribution to the Brazilian tributary administration must be highlighted in this part. At a first moment, about the mission, it is important to consider that the advances and the modern contemporary society do not exempt an efficiently and continuous policy fiscal education. Once that pay the tax to the State, is beyond of a right, is an act of citizenship, which fiscal conscience must be permanent developed as a factor of culture and of participation in the maintain of the State, wanted and created by the respective society. Therefore, the mission of the tributary administration must consider the improvement and the strengthening of this citizenry culture and from the fiscal education. The analyzed mission, however, do not reflect to this concern.

In a second point, to the Brazilian tributary administration the example of those tributaries administrations that construct a vision of future considering the society confidence in this organization and in the tributary system, defending its integrity and preserve the confidence, must be, somehow, copied. The society needs to trust in the institution, valuing it and recognizing its actions. Therefore, a strategic orientation related to a construction of confidence needs to be improved. Simplifying the system is important, but this action, common to the tributaries administrations, does not necessarily reflect in the society confidence in the organization, but in attend their demands. The confidence and the respect of the organization, by the society, in general, require, for the right, other actions. It is necessary identify, in the society, what it expect from the tributary administration in the realization of their mission, besides of being a facilitator of the compliance of the taxes obligation, and construct a vision of future that consider that expectative, minimizing the risk of construct an strategic orientation disconnected of this society.

In addition, some values of RFB, even that are present in their action, they are no present in their strategic planning. The strategic orientation could embrace values as the efficiently communication with the society, aligning this element as strategic orientation to the future of being connected to the society expectation to the tributary administration. The value of 
transparency is present in the strategic planning of the RFB, it is not performed without an effective communication value. The realization of that depends on other. The cooperation and the collaboration with other tributaries administration do not seem as value that could be realized in their actions. The cooperation, in an intern or extern level, in the contemporary society seem as fundamental value.

\section{References}

Abib, G., \& Hoppen, N. (2015). O papel do consultor no processo de alinhamento estratégico. RAC, p. 584-605.

AFIP. (2015). ADMINISTRACIÓN FEDERAL DE INGRESSOS PÚBLICOS. Plan estratégico 2011-2015.Avaible in: tp://www.afip.gob.ar/institucional/documentos/planestrategicoafip20112015.pdf >. Acessed in Oct. $16^{\text {th }} \cdot 2017$.

AFIP. (2017). ADMINISTRACIÓN FEDERAL DE INGRESSOS PÚBLICOS. Plan de Gestión $\quad$ AFIP $2017 . \quad$ Aviable in: <http://www.afip.gob.ar/institucional/Documentos/PlanGestionAFIP2017.pdf>. Acessed in: Out. $16 \mathrm{t}^{\text {th }} 2017$.

Beuren, I. M. (2009). Como Elaborar Trabalhos Monográficos em Contabilidade: teoria e prática. São Paulo: Atlas.

CTN (1966). BRASIL. Código Tributário Nacional (1966). Avaible in: <http://www.planalto.gov.br/ccivil_03/leis/15172.htm>. Acessed in: Fev. $15^{\text {th }} 2017$.

Constitução Federal do Brasil (1998). Avaiable in: <http://www.planalto.gov.br/ccivil_03/constituicao/constituicaocompilado.htm>. Acessed in: Fev. 1st. 2017.

BRASIL. (2007). Lei $\mathrm{n}^{\mathrm{o}}$ 11.457/2007. Avaiable in: <http://www.planalto.gov.br/ccivil_03/_ato2007-2010/2007/lei/111457.htm>. Acessed in: Fev. $15^{\text {th }} 2017$.

CIAT. (2015). Uma visão geral da atuação das Administrações Tributárias. In: Curso de administração tributária: Centro Interamericano de Administrações Tributárias. 2015.

CRA. (2017). CANADA REVENUE AGENCY. About the Canada Revenue Agency (CRA). Avaiable

in: <https://www.canada.ca/en/revenue-agency/corporate/about-canada-revenue-agency-cra.html $>$. Acessed in: Dez. $4^{\text {th }} 2017$.

CRA (2017). CANADA REVENUE AGENCY. Summary of the Corportate Busines Plan 2017-2018 to 2019-2020. Avaiable in: <https://www.canada.ca/en/revenue-agency/corporate >. Acessed in: dez. $4^{\text {th }} 2017$.

DGI. (2015). DIRECCION GENERAL IMPOSITIVA. Plan Estratégico de Gestión 2015-2019. Avaliable in: <http://www.dgi.gub.uy/wdgi/page?2,principal. Acessed in: Dez $4^{\text {th }}$ 
2017.

Fischmann, A. A., \& Almeida, M. I. R. de (1991). Planejamento estratégico na prática. 2a. ed. ed. São Paulo: Atlas.

Ghemawat, P. (2000). A estratégia e o cenário dos negócios: textos e casos. Tradução de Nivaldo Montingelli Jr.

Godoy, A. S. (1995). A pesquisa qualitativa e sua utilização em administração de empresas. Revista de administração de empresas, 35(4), 65-71.

Godoy, A. S. (1995a). Pesquisa Qualitativa: tipos fundamentais. Revista de Administração de Empresas, 35(3), 20-29. https://doi.org/10.1590/S0034-75901995000300004

Godoy, A. S. (1995b). Introdução à pesquisa qualitativa e suas possibilidades. Revista de Administração de Empresas, https://doi.org/10.1590/S0034-75901995000200008

IRS. (2017). INTERNAL REVENUE SERVICE (2017). Strategic Plan FY2014-2017. Avaiable in: <https://www.irs.gov/pub/irs-pdf/p3744.pdf>. Acessed in: dez. $3^{\text {th }}$.

Malhotra, N. K. (2001). Pesquisa de Marketing: uma orientação aplicada. 3a. ed. Porto Alegre: Bookman: Bookman.

Pereira, M. F., de Agapito, F., Estrada, R. J. S., \& de Almeida, M. I. R. (2007). Afinal, como se formam as estratégias? O processo de formulação estratégica em uma organização do terceiro setor. RAI-Revista de Administração e Inovação, 3(1), 56-75.

Pereira, L. C. B. (1998). Gestão do setor público: estratégia e estrutura para um novo Estado. Reforma do Estado e administração pública gerencial, 1, 21-38.

RFB. (2017). SECRETARIA DA RECEITA FEDERAL DO BRASIL. Mapa estratégico da RFB. Avaiable in: <http://idg.receita.fazenda.gov.br/sobre/institucional/planejamento-estrategico/rfb-mapa-estra tegico-2016-2019_com-descritivos-tam-a3.pdf>. Acessed in: Nov. $1^{\text {st }} 2017$.

RFB. (2017). COPAV. Análise de cenários prospectivos 2022. Avaiable in: <intranet RFB>. Acessed in: Mar. $31^{\text {th }} 2017$.

RFB. (2018). SECRETARIA DA RECEITA FEDERAL DO BRASIL. Resultado da Arrecadação. Disponível em: <http://idg.receita.fazenda.gov.br/dados/receitadata/arrecadacao >. Acessed in: Mar. $18^{\text {th }}$ 2018.

SET (2017). SUBSECRETARÍA DE ESTADO DE TRIBUTACIÓN. Plano estratégico 2014 2018. Avaiable in: $<$ http://www.set.gov.py/portal/PARAGUAY-SET/Documentos/Institucional?folder-id=reposit ory:collaboration:/sites/PARAGUAY-SET/categories/SET/Institucional/plan-estrategico>. Acessed in Oct. $16^{\text {th }} 2017$. 
SII. (2017). SERVICIO DE IMPUESTOS INTERNOS. Plan estratégico 2017-2021. Avaiable in: <http://www.sii.cl/sobre_el_sii/plan_estrategico_sii.pdf>. Acessed in: Dez. $4^{\text {th }} 2017$.

Stewart, J. (2004). The meaning of strategy in the public sector. Australian Journal of Public Administration, 63(4), 16-21. https://doi.org/10.1111/j.1467-8500.2004.00409.x

\section{Copyright Disclaimer}

Copyright for this article is retained by the author(s), with first publication rights granted to the journal.

This is an open-access article distributed under the terms and conditions of the Creative Commons Attribution license (http://creativecommons.org/licenses/by/4.0/). 